\title{
ENTRY TO PROBLEMATICS OF TECHNOLOGY SUPPORT AND PATENTING IN DEVELOPING EU COUNTRIES
}

\author{
[Vstup do problematiky technologickej podpory a patentovania v rozvíjajúcich \\ sa krajinách EÚ]
}

\author{
Marek Jemala ${ }^{1}$, L'ubomír Jemala ${ }^{2}$ \\ ${ }^{1}$ Slovenská technická univerzita, Materiálovotechnologická fakulta, Ulica Jána Bottu č. 2781/25, 91724 \\ Trnava \\ Email:marek.jemala@stuba.sk
}

${ }^{2}$ Slovenská technická univerzita, Ústav manažmentu, Vazovova 2757/5, 81243 Bratislava-Staré Mesto Email:lubomir.jemala@stuba.sk

\begin{abstract}
This study complements our long-term systemic research so as to promote technological innovation in the EU countries. The main research goal of this study is to examine technological innovation in the developing EU countries and to identify positive and negative technology innovation-related processes. In terms of the methodology of this research, as the main method was chosen Patent analysis of the WIPO database (1980-2014), which we perform in a long term. The patent data were analyzed, verified and summarized for the purposes of this study and subsequently completed by Bibliometric analysis of the technological innovation activities in these countries - for identifying relevant trends. In the analytical part of our study was in particular examined the overall development of technology patents in the developing EU countries. According to these indicators, among the most successful technology developing countries in the EU mainly belong Poland, Hungary, Romania, and the more successful are also Greece and Bulgaria. Such a long-term study in our conditions has not been realized yet.
\end{abstract}

Keywords: technological innovation, technology developing EU countries, technology patents, technology research and development.

JEL classification: $\mathrm{O} 31, \mathrm{O} 32, \mathrm{O} 33, \mathrm{O} 34, \mathrm{P} 30$

Doručeno redakci: 23.2.2017; Recenzováno: 14.3.2017; 20.3.2017; Schváleno k publikování: 31.5.2017

\section{Úvod}

Inovačné procesy povzbudzujú firmy, aby prekročili svoje hranice, pretransformovali svoje myšlienky/invencie do nových výrobkov, technológií i služieb a zmenili konvenčné prístupy na kreatívne postupy vo všetkých oblastiach podnikania. Inovačné procesy firiem vyžadujú neustále učenie a prispôsobovanie sa prostrediu, technologickému pokroku, spoluprácu a integráciu firmy s prostredím (Russell, Taylor 2014). Od roku 2000 sú zavádzané nové prístupy $\mathrm{v}$ manažmente inovácií/technológií, pokial ide o stále dôležitejšiu ekologickú stránku technológií, alebo podporu motivácií a kreativity všetkých zamestnancov podniku už v rannej fáze inovácií (Edgington 2008). Na základe predchádzajúceho výskumu, len približne 10-12\% firiem úspešne realizuje svoje inovácie a len asi polovica z nich využíva systémové $1 /$ dlhodobé prístupy $\mathrm{k}$ manažmentu inovácií (Tidd, Bessant 2015). Aj v rozvíjajúcich sa ekonomikách rastú tendencie medzinárodných spoločností skupovat' progresívne technologické startupy, vyžívat' stratégie otvorených inovácií (Christensen,

\footnotetext{
1 Systémová analýza $\mathrm{v}$ rámci tohto výskumu znamená dlhodobejšie a komplexnejšie skúmanie, porovnávanie a vyhodnocovanie nielen výsledkov inovačnej aktivity jednotlivých krajín, ale aj použivaných metód, metodík ich štúdia a sledovanie komplexnejších príčin, väzieb a dopadov tejto aktivity, atd'. V rámci jednej štúdie, ale nieje môžné podrobne sledovat' všetky inovačné väzby a efekty, preto je tento výskum zameraný hlavne na tie krajiny, ktoré dosahujú najlepšie a najslabšie výsledky v rámci parciálnej analýzy.
} 
Raynor 2003), multisourcing pri transfere technológií, Cloud computing, Big-data pri správe technológií, alebo najnovšie trendy Industry $4.0^{2}$, skôr ako nadmerne investovat' do rozvoja vlastných výskumných kapacít a existujúcich technológií. Toto si však často vyžaduje získavat' aj verejnú (aj medzinárodnú) podporu pre výskumné aktivity, inteligentnú špecializáciu firiem a regiónov, spoluprácu firiem (aj konkurentov a zákazníkov) pri technologickom $\mathrm{VaV}$, transfere technológií a systém účinnej (preventívnej) ochrany duševného vlastníctva (DV). Mnoho vlád (aj v rozvíjajúcich sa krajinách EÚ) postupne reaguje na tieto trendy tým, že pripravuje (vo väčšej, alebo menšej miere) zákony, stratégie a programy pre podporu/vytváranie inštitucionálnych sietí pre firemné, regionálne a národné systémy technologických inovácií (s väčším či menším úspechom).

V poslednom období, významnou otázkou technologického rozvoja je však aj tzv. absorpčná kapacita domácej ekonomiky/firiem. Rozvíjajúce sa krajiny majú často obmedzené kapacity nielen vyvinút', ale aj absorbovat' nové technológie, ktoré sú preto viac využívané vo vyspelejších ekonomikách. Je však potrebné aj prostredníctvom znalostného manažmentu rozvíjat' schopnost' rozpoznat' a využit' technologické príležitosti globálneho trhu. Priaznivý patentový systém môže podporit' technologické inovácie aj vtedy, pokial' budú patenty využívané vo vyspelých ekonomikách a domáca ekonomika získa výhody patentových príjmov.

V rozvinutých menších ekonomikách je technologický vývoj tiež značne závislí na zahraničných investíciách a know-how a vel'ká väčšina príjmov z technologických patentov smeruje do zahraničia a nie do domácej ekonomiky. V rozvíjajúcich sa ekonomikách zahraniční investori a firmy často kontrolujú až 75-90\% udelených patentov a súvisiacich príjmov (ECB 2016). Zahraničné firmy však často pomáhajú domácim priemyselným podnikom s transferom technológií po technickej, ekonomickej i manažérskej stránke, sú však odberatel'mi hlavných výhod súvisiacich s technologickým rozvojom. V menších vyspelých ekonomikách je často väčšina technologického potenciálu a know-how patentovaná. Technológie, ktoré nie sú patentované, je t’ažšie predat' formou licencie, a tak sú limitované na použitie prevažne $\mathrm{v}$ domácom prostredí. Celkovo existuje stále významný rozdiel $\mathrm{v}$ podpore a manažmente technologických inovácií v týchto dvoch typoch krajín.

V d’alšej viac problémovo-metodickej kapitole tejto štúdie je preto výskumným ciel'om poukázat' na niektoré dôležité aspekty podpory technologických inovácií, ktoré môžu byt' aplikované aj v rozvíjajúcich sa krajinách EÚ. Medzi tieto aspekty možno zaradit' aj: potrebu hodnotenia aj dlhodobejších účinkov technologických inovácií a potrebu zefektívňovania podpory technologického $\mathrm{VaV}$.

\section{Vybrané problémovo-metodické aspekty podpory technologických inovácií v rozvíjajúcich sa krajinách EÚ}

V rozvíjajúcich sa krajinách žije viac ako $2 / 3$ svetovej populácie. Podiel rozvíjajúcich sa krajín na celosvetovom HDP sa zvýšil z menej ako $20 \%$ začiatkom 90 . rokov na súčasných viac ako 30\%. (ECB 2016) Pokial' ide o EÚ, rastúci vplyv rozvíjajúcich sa ekonomík prináša viacero príležitostí aj v technologickej oblasti. Výrazný ekonomický rast týchto krajín zvyšuje

\footnotetext{
2 Výrobné a súvisiace procesy budú podporované autonómnymi robotmi, s využitím Big-data, Cloud computingu, simulácií/rozšírenej reality, alebo 3D tlače. Vzniknú nové globálne siete založené na prepojení výrobných technológií a tzv. cyber-physical systems (inteligentné entity). Tieto prepojenia umožnia podniku $\mathrm{V}$ reálnom čase reagovat' na zmeny v prostredí i vo výrobe. Vzniknú nové obchodné modely, tzv. fraktálny, inteligentný podnik (decentralizované, autonómne, inteligentné OŠ) a bude uplatňovaná globálna optimalizácia pri využívaní zdrojov/kapacít/technológií výroby atd'.
} 
dopyt po mnohých tovaroch i službách, a tak aj po technológiách, v prípade ktorých má EÚ určitú konkurenčnú výhodu. Konkurencia zo strany rozvíjajúcich sa krajín tiež motivuje rozvinuté členské krajiny rýchlejšie napredovat' $v$ realizácii štrukturálnych reforiem i podpore vedy a výskumu (VaV). Technologické inovácie v rozvíjajúcich ekonomikách (primerané podporované štátom, firmami i spoločnost'ou) môžu z dlhodobejšieho hl'adiska prispiet' aj k pozitívnej reštrukturalizácii ekonomického kapitálu a kapacít najmä priemyselných podnikov, ale celkovo aj k lepšiemu potenciálu ekonomiky a štátu. Môžu podporovat' pružnejšiu a efektívnejšiu organizáciu výrobných procesov (Yang 2005), otvorenú spoluprácu s dodávatel'mi, konkurentmi, alebo zákazníkmi; vytváranie nových odvetví; zlepšenie podnikatel'skej a socio-environmentálnej udržatel'nosti; atd'. Ale, nová technológia môže byt' tiež vel'mi rušivá pre svoje prostredie. Môže vyžadovat' neustále investície, viac dodávatel'ov, nové obchodné modely, prepúšt’anie zamestnancov, nové riešenia na zníženie nákladov, odpadov, alebo emisií. Toto môže vyvolat' zvýšenie cien, vznik monopolov a nové riziká pre spoločnost' a životné prostredie. Pre lepšiu konkurencieschopnost' regiónu a krajiny môžu byt' podporované technológie, ktoré nemajú úplne preskúmaný dlhodobý vplyv na zdravie obyvatel'stva, pozitívne kultúrne tradície, životné prostredie (napr. biotechnológie, genetické inžinierstvo, nanotechnológie, jadrová energia, internetové vyhl'adávače a iné IKT). Takáto "podpora" rozvíjajúcimi krajinami môže byt' krátkodobo ekonomicky účelná, ale $\mathrm{z}$ dlhodobého hl'adiska významne riziková pre daný región a štát. Preto je potrebné aj v týchto krajinách unifikovat' a neustále kontrolovat' dodržiavanie (nielen stanovenie) medzinárodných noriem a pravidiel ovplyvňujúcich technologický rozvoj. Jednou z úloh zefektívňovania podpory technologického výskumu a vývoja (VaV) je zvyšovat' podiel súkromných investícií, aj pokial' ide o menšie technologické projekty (Dolata 2008, Dolata 2009). Zvýšenie tohto podielu však predpokladá zároveň účelnejšiu verejnú podporu súkromných investícií, aj pokial' ide o preberanie finančných záruk za technologický $\mathrm{VaV}$, sprostredkovanie účelných spojení medzi súkromným a akademickým sektorom, mapovanie trhu, legislatívnu podporu $\mathrm{VaV}$ a primeranú ochranu duševného vlastníctva (DV). Otázka efektívnosti technologických inovácií však musí zahŕňat' aj ich reálnu účelnost' a spomenuté dlhodobé vplyvy na spoločnost' a prostredie.

$\mathrm{Na}$ základe tejto kapitoly možno sumarizovat' niektoré výskumné otázky pre nasledujúcu analytickú kapitolu. Napríklad: ako sú technologické inovácie podporované v rozvíjajúcich sa krajinách EÚ? Aká je štruktúra technologických inovácií/priemyslu a ktoré odvetvia sú najviac podporované? Ktoré technológie sú najviac a najmenej podporované? Hlavným výskumným ciel’om následnej analytickej kapitoly je predovšetkým preskúmat' intenzitu technologických inovačných aktivít v rozvíjajúcich sa krajinách EÚ.

\section{Analytická štúdia technologických inovácií a patentov v rozvíjajúcich sa krajinách Eú}

Hlavným ciel'om tejto analytickej kapitoly je systémovo preskúmat' technologickú inovatívnost' rozvíjajúcich sa krajín EÚ spolu s vybranými ukazovatel'mi a charakteristikami na základe patentovej analýzy WIPO (1980-2014). Ako kl'účový ukazovatel'/kritérium tejto analýzy bolo zvolené množstvo udelených technologických patentov. V druhej časti tejto štúdie bol analyzovaný tento ukazovatel' v porovnaním s inými ukazovatel'mi, ako sú: počet obyvatel'ov krajiny, výška vytvoreného HDP a objem výdavkov na výskum a vývoj (VaV). Výsledky patentovej analýzy boli doplnené bibliometrickou analýzou inovačnej aktivity týchto krajín. Táto štúdia dopíňa náš dlhodobý výskum $\mathrm{s}$ názvom „Systémové patentové štúdie zamerané na podporu technologických inovácií v krajinách EÚ“, ktorý realizujeme už od roku 2010. Preto aj v tomto článku sú predstavované určité porovnania, ale aj zmeny ku ktorým prišlo v posledných rokoch $\mathrm{v}$ oblasti technologického vývoja v krajinách EÚ. Táto 
štúdia má aj niektoré obmedzenia, medzi hlavné patrí fakt, že nie všetky technologické inovácie sú patentované, niektoré nevyužívajú žiadnu formu ochrany DV, iné využívajú iné formy, ako sú priemyselné vzory, dizajnové práva, ochranné známky apod. Patent je však stále hlavnou a najúčinnejšou formou ochrany DV, a tak aj hlavným indikátorom inovačnej aktivity. Jedným z najdôležitejších kritérií deliacich krajiny na rozvinuté a rozvíjajúce je aj technologická úroveň priemyslu a spoločnosti. Podl'a stupňa industrializácie krajiny, životného štandardu a ekonomických kritérií, všetky krajiny EÚ, aj tzv. noví členovia môžu byt' považovaní za rozvinuté ekonomiky (UNDP 2015). Avšak z hl'adiska rozvoja znalostnej ekonomiky, podpory $\mathrm{VaV}$ a inovatívnosti, sofistikovanosti výroby a priemyslu, výšky vyprodukovanej pridanej hodnoty, stupňa automatizácie a informatizácie, ako aj podpory univerzitného vzdelávania a iných kritérií možno tzv. nových členov EÚ považovat' stále za rozvíjajúce sa krajiny.

\subsection{Najviac patentované technológie $v$ rozvíjajúcich sa krajinách EÚ}

Udelené patenty aj v technologickej oblasti môžu za určitých okolností vytvorit' bariéru pre následné inovácie, niekedy komercializácia inovácií vyžaduje použitie patentovanej technológie inej firmy, iné firmy môžu odmietnut' predat' licencie na svoje technológie, alebo môžu vyžadovat' vysoké licenčné poplatky, alebo ked' sú ochotní poskytnút' licenciu, je nutné koordinovat' vel'ké množstvo práv duševného vlastníctva (DV), čo nemusí byt' rentabilné. Na druhej strane udelenie výlučných práv na inováciu môže poskytnút' firmám vel'kú trhovú silu a schopnost' stanovit' ceny nad marginálne výrobné náklady. V niektorých prípadoch je táto konkurenčná výhoda obmedzená zo strany dodávatel'ov náhradných, alebo súvisiacich technológií a výrobkov iných firiem. (WIPO 2015) Jednotný patentový systém by mohol ul'ahčit' patentovanie technológií aj v rozvíjajúcich sa krajinách, ale na druhej strane je tu riziko, že mnohé udelené patenty a súvisiace výhody by plynuli viac do rozvinutých ekonomík sveta, a to najmä $\mathrm{z}$ dôvodu lepšieho inovačného, technologického i trhového potenciálu. $\mathrm{V}$ mnohých prípadoch by patentové príjmy mohli viac smerovat' do materských firiem globálnych korporácií, a to aj ked' inovátori pochádzajú z rozvíjajúcich sa krajín a z menších firiem. Takýto patentový systém by mohol ešte viac podporovat' bohatšie firmy a krajiny a naopak. (Tvedt 2010) Národné patentové úrady majú mat' preto stále aj určitú podpornú funkciu pri inovačnom rozvoji danej krajiny. V súčasnej dobe je často také náročné ochránit' svoju technológiu, ako ju vyvinút' atd'. Toto sú len niektoré dôležité aspekty možnej podpory, alebo obmedzovania patentovej aktivity rozvíjajúcich sa krajín.

Ak by sme sa pozreli na patentovú analýzu vydaných technologických patentov registrovaných v databáze WIPO (1980-2014), potom by sme zistili, že najviac patentované technológie v rozvíjajúcich sa krajinách EÚ sú v kategórii: organická jemná chémia $(10,2 \%)$, nasledujú farmaceutické technológie (7,6\%) a stavebné inžinierstvo (6,2\%). Celkovo v krajinách EÚ sú najviac patentované dopravné zariadenia (6,3\%), stavebné inžinierstvo $(6,2 \%)$ a elektrické zariadenia, prístroje, energia $(5,8 \%)$. V tomto porovnaní, s výnimkou stavebného inžinierstva, existujú významné rozdiely v prioritách výskumu v rozvíjajúcich sa krajinách EÚ. Napríklad organická (jemná) chémia zahŕňa celý rad chemických látok, ktoré sú vyrábané $\mathrm{v}$ menších objemoch, a to predovšetkým dávkovým procesom, pri použití viacúčelových zariadení (IPTS 2016). Tieto produkty sú typicky s vyššou pridanou hodnotou (PH) a predávané zvyčajne d’alším medzinárodným spracovatel'ským spoločnostiam, ktoré z nich vyrábajú finálne výrobky (napr. známe značky ako Avon, L'Oreal, alebo Nivea). Okrem spomenutých rizík, určitým problémom je tu často aj vyššie environmentálne zat'aženie tejto výroby pre rozvíjajúce sa krajiny EÚ. Vo všeobecnosti nedostatočná inovačná aktivita a súvisiaca podporná infraštruktúra môžu byt' hlavnými príčinami nižšieho rozvoja farmaceutického priemyslu v krajinách EÚ. Farmaceutický priemysel má však dlhodobú 
tradíciu v krajinách EÚ (napr. firmy ako sú Bayer Schering Pharma; C.H. Boehringer Sohn AG \& Ko. KG; alebo Glaxo atd’.). Tieto a iné medzinárodné firmy prevzali mnohé menšie farmaceutické spoločnosti v rozvíjajúcich sa krajinách EÚ v posledných rokoch a využívajú výhody založené na tradíciách lokálnych značiek. Celkovo problematika generík, rýchlo rastúce trhy v Brazílii, Č́ne a Indii, rastúce legislatívne požiadavky na tento výskum a iné príčiny spôsobujú neustále oslabovanie farmaceutického priemyslu v rozvíjajúcich sa krajinách EÚ (EFPIA 2014). Tret'ou najviac podporovanou technologickou kategóriou v rozvíjajúcich sa krajinách EÚ je stavebné inžinierstvo. Kvôli Globálnej ekonomickej kríze, najmä v období 2010-2014, aj rozvíjajúce sa krajiny ako Chorvátsko, Cyprus, Grécko a Slovensko a iné zaznamenali negatívny rast vo svojej stavebnej činnosti. Naopak pozitívny nárast bol registrovaný najmä v Pol'sku a na Malte. Počas roku 2014 a prvej polovice roku 2015 došlo opät' k miernemu poklesu v inžinierskej činnosti v krajinách EÚ, v posledných mesiacoch roku 2015 nasledovalo už mierne oživenie. (EC 2015b) Rozvoj technológií v rámci stavebného inžinierstva je nutný najmä $\mathrm{z}$ dôvodu zabezpečenia vyššej produktivity práce, primeraným mzdovým nákladom a vyššej ziskovosti týchto projektov.

Z časového hl'adiska tejto analýzy rozvíjajúce sa ekonomiky terajšej EÚ tvorili samostatné štáty v 80-tych rokoch a ešte neskôr. ${ }^{3}$ Podl'a tejto analýzy bolo však v rozvíjajúcich sa krajinách EÚ vydaných najviac patentov v rokoch 1980-1985 a v rokoch 1986-1990 v čase komunizmu a ich relatívnej samostatnosti, od vtedy počet vydaných technologických patentov značne klesá. Rovnaký stav je aj v ostatných členských krajinách EÚ. Preto aj v oblasti podpory technologických inovácií v krajinách EÚ je potrebné systémovo nadväzovat' na tradície, hodnoty a komparatívne výhody jednotlivých členských krajín. Naopak najmenej patentované technológie v rozvíjajúcich sa krajinách EÚ sú mikroštrukturálne technológie a nanotechnológie $(0,03 \%)$, IT pre manažment $(0,06 \%)$ a digitálna komunikácia $(0,3 \%)$. V krajinách EÚ celkovo sú najmenej patentované mikroštrukturálne technológie a nanotechnológie $(0,04 \%)$, IT pre manažment $(0,1 \%)$ a analýza biologických materiálov $(0,5 \%)$. Bezpečný výskum v oblasti nanotechnológií však ponúka (aj pre rozvíjajúce sa krajiny EÚ) vel'ký potenciál pre podporu udržatel'ného ekonomického rastu, zlepšenie konkurencieschopnosti priemyslu, lepšiu ochranu životného prostredia, vytváranie vysoko kvalifikovaných pracovných miest a zlepšovanie kvality života. $\mathrm{Na}$ druhej strane nie je doteraz $\mathrm{k}$ dispozícii dostatok vedeckých garancií, pokial' ide o vylúčenie možných toxických a iných nebezpečných vlastností všetkých nanotechnológií. ${ }^{4}$ (Cordis 2008, EC 2009) Medzi rozvinutými i rozvojovými krajinami je preto potrebná systémová medzinárodná spolupráca aj v oblasti výskumu nanotechnológií. Štandardizácia vrátane dostupnosti referenčných materiálov je klúčovou otázkou aj pre hodnotenie rizík nanotechnológií (NT). Napriek tomu, krajiny EÚ-28 predstavovali najviac 41,6\% z celkového počtu patentových prihlášok v kategórií NT v rámci EPO, nasledovali USA $(23,0 \%)$, Japonsko (15,9\%) a Južná Kórea (6,2\%) (Jemala 2015). Inovácie v oblasti IKT sú rozhodujúce pre hospodársky rast aj v rozvíjajúcich sa krajinách EÚ. Digitálna ekonomika rastie približne

\footnotetext{
3 V roku 1981 rozširovanie Európskeho spoločenstva (ES) sa realizovalo vstupom Grécka. Československo, Pol'sko, Mad'arsko, Rumunsko a Bulharsko boli stále súčast’ou tzv. komunistického bloku bývalej ZSSR. Jednotný Európsky Akt (od roku 1987) priniesol novú iniciatívu v rámci európskej integrácie a posunu Európskeho spoločenstva k myšlienke jednotného európskeho trhu. Najdôležitejším dokumentom pre vznik EÚ bolo podpísanie Zmluvy o Európskej únii v Maastrichte v roku 1992. Neskôr v roku 2004 v rámci najväčšieho rozšírenia EÚ pristúpilo 10 (podl’a tejto štúdie technologicky rozvíjajúcich sa) krajín: Cyprus, Česká republika, Estónsko, Litva, Lotyšsko, Mad'arsko, Malta, Pol'sko, Slovensko a Slovinsko. V roku 2007 pristúpilo Bulharsko a Rumunsko, a v roku 2013 Chorvátsko. [EUROPARL.EUROPA, 2016]

${ }^{4}$ Hoci nanočastice sa môžu nachádzat' v prostredí aj prirodzene, alebo byt' neúmyselne produkty priemyselného procesu.
} 
7 krát rýchlejšie ako zvyšok ekonomiky. Rozvoj vysokorýchlostných širokopásmových sieti môže mat' rovnaký dopad na ekonomiku, ako rozširovanie elektrických a dopravných sietí pred sto rokmi. Tieto inovácie sú základom pre mnohé d'alšie inovácie, ako sú inovatívne služby e-Health, inteligentné mestá a výroby riadené počítačmi. (EC 2014) Najvyššie počty patentových prihlášok $\mathrm{v}$ kategórii IKT boli zaznamenané $\mathrm{v}$ rozvinutých ekonomikách $\mathrm{v}$ Nemecku, Francúzsku, a Vel'kej Británii. Na základe patentovej analýzy, IKT i mnohé progresívne technológie sú značne podporované v krajinách EÚ, ale sú často len vo fáze základného výskumu. Aplikovaný výskum je často stále menej efektívny. Je tiež známe, že mnohé európske výskumné tímy často duplikujú výskum a vývoj ( $\mathrm{VaV})$ v týchto oblastiach. Iným problémom môže byt' slabšia infraštruktúra, pokial' ide o ochranu DV a transfer technológií. V krajinách EÚ nie je možné napríklad patentovat' SW. Inovácie v oblasti IT pre manažment nie sú vel'mi podporované v rozvíjajúcich sa krajinách EÚ. Celkovo je evidovaných v databáze WIPO (1980-2014) 354965 technologických patentov pri rozvíjajúcich sa krajinách EÚ a 2528612 patentov pri všetkých krajinách EÚ. Rozvíjajúce sa krajiny sa teda podiel'ajú na patentovaní technológií približne len $14 \%$. Najväčší pokles v patentovej aktivite zaznamenali Malta, Cyprus a Grécko. V relatívnom vyjadrení bol zaznamenaný najväčší celkový nárast patentovej aktivity v prípade Estónska a Pol'ska. Napríklad Č́na eviduje približne 1288342 technologických patentov, Rusko 563203 , Japonsko 2895 011, a USA 5413873 technologických patentov v porovnatel'nom období (USPTO 2014) (Obrázok 1, Tab. 1 a 2)

Obrázok 1: Udelené technologické patenty v rozvíjajúcich sa krajinách EÚ, WIPO (19802014)

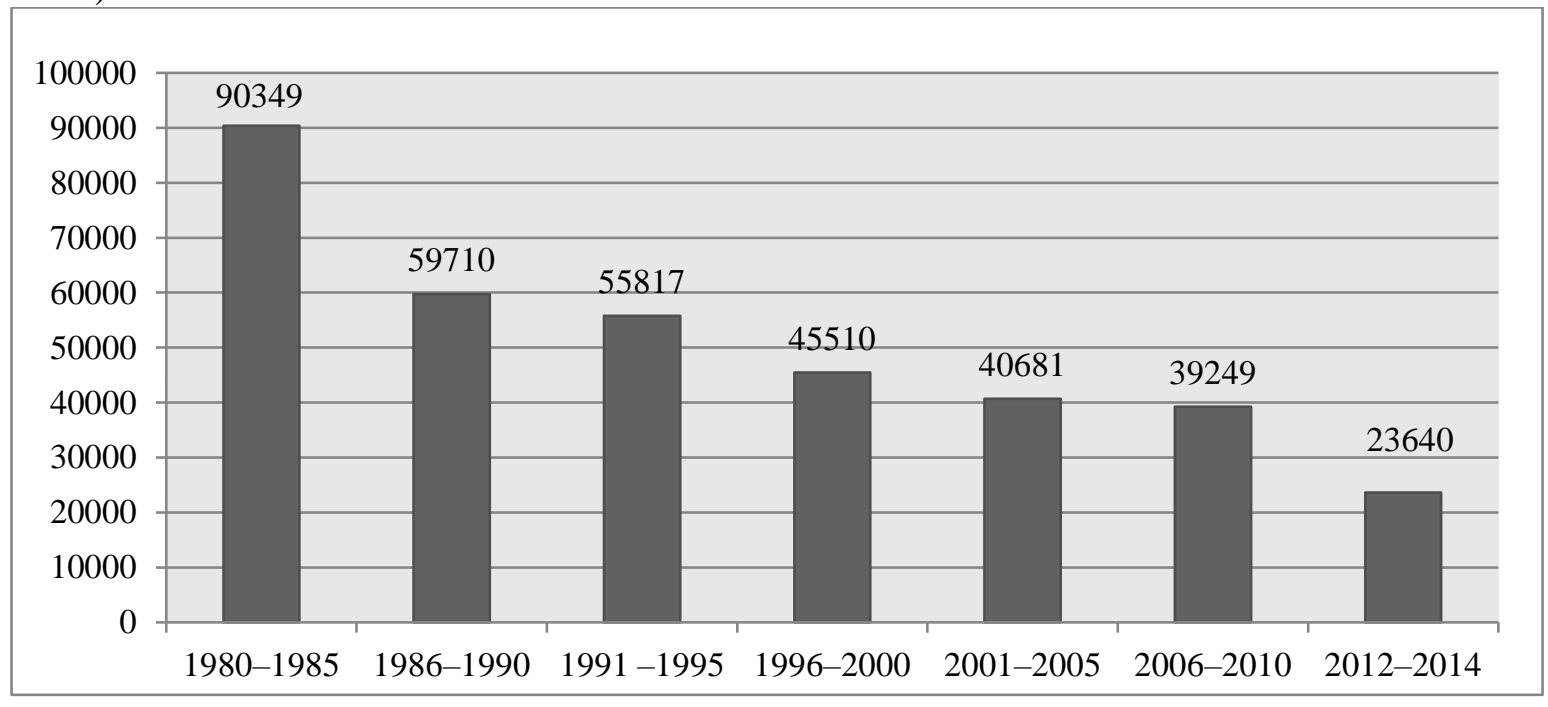

Zdroj: Vlastná štatistika na základe údajov (WIPO 2016) 
Tabul'ka 1: Udelené technologické patenty v rozvíjajúcich sa krajinách EÚ, WIPO (1980-2014) čast' A.

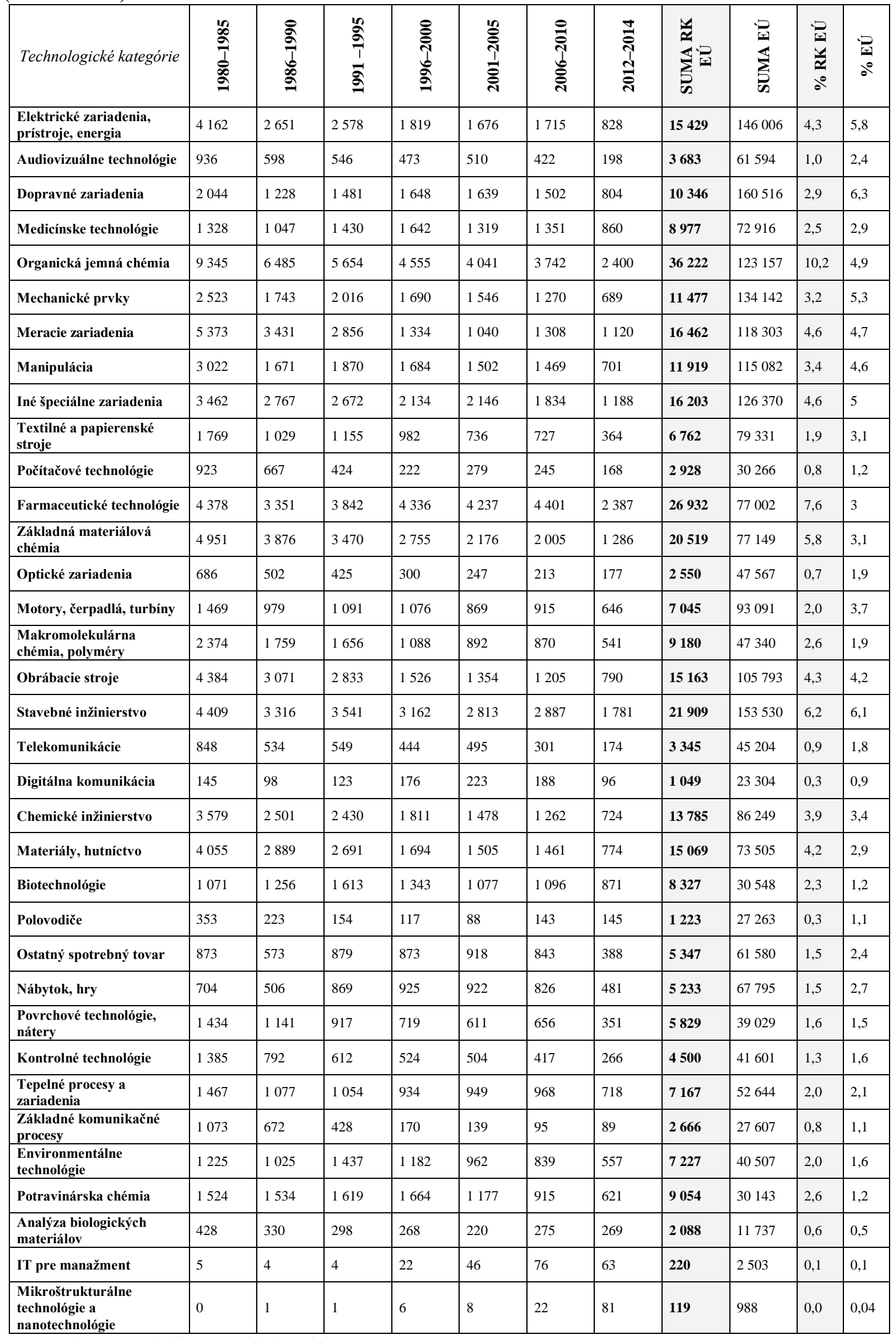

Zdroj: Vlastná štatistika na základe údajov (WIPO 2016) 
Tabul'ka 2: Udelené technologické patenty v rozvíjajúcich sa krajinách EÚ, WIPO (1980-2014), čast' B.

\begin{tabular}{|c|c|c|c|c|c|c|c|c|c|c|c|}
\hline Technologické kategórie & $\begin{array}{l}\mathscr{0} \\
\frac{1}{1} \\
\stackrel{2}{2}\end{array}$ & 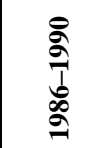 & $\frac{2}{\sigma}$ & 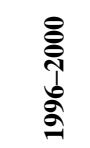 & 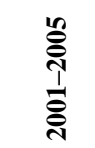 & 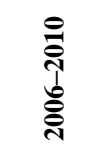 & 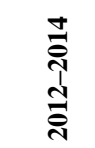 & 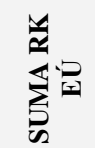 & 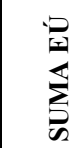 & 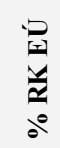 & $\begin{array}{l}\text { D } \\
\text { o }\end{array}$ \\
\hline Iné technológie & 12642 & 4383 & 599 & 212 & 337 & 785 & 44 & 19002 & 97250 & 5,4 & 3,8 \\
\hline SUMA RK EÚ & 90349 & 59710 & 55817 & 45510 & 40681 & 39249 & 23640 & 354965 & - & 100 & 100 \\
\hline SUMA EÚ & 714017 & 514221 & 337441 & 305225 & 280868 & 245913 & 130927 & - & - & - & - \\
\hline \% RK EÚ & 25,5 & 16,8 & 15,7 & 12,8 & 11,5 & 11,1 & 6,7 & - & - & - & - \\
\hline$\%$ EÚ & 28,2 & 20,3 & 13,3 & 12,1 & 11,1 & 9,7 & 5,2 & - & - & - & ـ \\
\hline
\end{tabular}

\subsection{Najúspešnejšie rozvíjajúce sa krajiny EÚ na základe vydaných technologických patentov}

Celková inovačná intenzita je značne rozdielna aj medzi rozvíjajúcimi sa krajinami EÚ. Niektoré krajiny (Estónsko, ČR, SR, Cyprus, Malta, Pol'sko, Chorvátsko, Lotyšsko, Mad'arsko, alebo Grécko) sú na tom lepšie, ale stále sú len tzv. miernymi inovátormi v oblasti inovačnej dynamiky v rámci EÚ. Mnohé rozvíjajúce sa krajiny majú svoje technologické patenty, ale ide skôr o inovácie nižšieho rádu, zväčša na úrovni regiónu, alebo menšieho odvetvia. Rozvíjajúce sa krajiny preberajú často množstvo inovácií formou transferu technológií. Nejde len o množstvo patentov, ale v tomto kontexte je tu aj otázka, čo stále bráni týmto krajinám rozvinút' viac radikálne technologické zlepšenia? Napríklad, inovatívnost' Litvy, Rumunska, alebo Bulharska je však značne pod priemerom EÚ-28. (EC 2013, EC 2015a) Postavenie Cypru a Estónska sa v poslednom období ešte zhoršilo. Pri týchto krajinách môže byt' výskumná otázka, aké sú hlavné príčiny ich celkového inovačného zaostávania? Z hladiska celkovej inovačnej dynamiky v rámci týchto krajín má najlepšie výsledky Slovinsko, neplatí to však v technologickej oblasti. Rumunsko má naopak pomerne vysoký počet technologických patentov, v celkovej inovačnej dynamike však značne zaostáva.

$\mathrm{Ak}$ sa pozrieme na počet technologických patentov registrovaných $v$ rámci WIPO (1980-2014), potom v rozvíjajúcich sa krajinách EÚ dominujú Pol’sko, Mad’arsko a Rumunsko. Najmenšie množstvo technologických patentov bolo registrované na Malte, $\mathrm{v}$ Estónsku a Litve. Napr. Cyprus neregistroval žiadne technologické patenty v databáze WIPO v období 1980-2014, napriek tomu patrí k tzv. miernym inovátorom v rámci týchto krajín podl'a výskumu EK (EC 2015a). Z hl'adiska významného technologického zaostávania Cypru, môže existovat' niekol'ko kl'účových príčin. Cyprus vstúpil do Európskej patentovej organizácie a stal sa členom Zmluvy o patentovej spolupráci až v roku 1997. Až v roku 1998 Cyperská vláda prijala nový patentový zákon. Ale napriek tomu Cyprus nemá žiadne špecializované súdy, ktoré by sa zaoberali právami/porušovaním DV (Tramountanelli 2010). ${ }^{5}$ Okrem toho, výrobné odvetvie Cypru sa skladá len z malého počtu výrobcov a technologických inovátorov, preto nedochádza ku väčšej konkurencii a často ani $\mathrm{k}$ porušovaniu patentových práv. Takýto stav môže byt' tiež jedným z dôvodov inovačného zaostávania mnohých malých rozvíjajúcich sa krajín, aj pokial' ide o podporu radikálnejších inovácií. V poslednom období sa inovačné výsledky Cypru zhoršili aj z týchto dôvodov: pokles výdavkov na $\mathrm{VaV}$ v podnikatel'skom sektore a pokles inovačných príjmov zo

\footnotetext{
${ }^{5}$ Cyprus nemá svoj patentový úrad, otázkami DV sa zaoberá Odbor registra spoločností a konkurzného komisára Cyperskej republiky, ktorý zabezpečuje len základné služby.
} 
zahraničia (EC 2015a). Medzi najvýznamnejšie inštitúcie v oblasti technologických inovácií na Cypre patria (okrem výskumných centier v rámci univerzít) napr. Cyperský inštitút s 6 výskumnými centrami ${ }^{6}$ a Cyperský medzinárodný inštitút pre životné prostredie a verejné zdravie, ktorý je napojený na Harvard University (CIPA 2016).

Úspešnou krajinou v tomto celkovom hodnotení je napríklad Pol'sko. Inovačná výkonnost' Pol'ska má však cyklický charakter. V rokoch 2012-2013 bol zaznamenaný mierny pokles a v roku 2014 mierny nárast tejto výkonnosti. Horší stav oproti priemeru EÚ je v oblasti otvorenosti, atraktívnosti a excelentnosti výskumnej základne a vzt’ahov s priemyslom, ako aj značným regionálnym rozdielom (Nowak 2009). Toto je d'alším problémom väčšiny rozvíjajúcich sa krajín EÚ. Vyniká najmä mesto/región Gliwice, ako jedno $\mathrm{z}$ najvýznamnejších pol'ských centier inovácií. V meste existuje množstvo inovačných firiem a inštitúcií. ${ }^{7}$ Táto inovačná infraštruktúra však chýba $\mathrm{v}$ mnohých iných regiónoch Pol'ska. Relatívnou výhodou Pol'ska sú aj nevýskumné inovačné výdavky, nárast $\mathrm{v}$ inovačných príjmoch, alebo nárast výdavkov na výskum a vývoj $(\mathrm{VaV})$ v podnikatel'skej oblasti. V roku 2013 Pol'sko oznámilo, že zahraničné firmy prispievajú menej ako 40\% z celkových zahraničných finančných prostriedkov na $\mathrm{VaV}$, a to predovšetkým pre rozšírené financovanie z fondov EÚ a iných medzinárodných organizácií (OECD 2013). Technologické inovácie, ich šírenie a absorpcia v Pol'sku, ale aj v d'alších rozvíjajúcich sa krajinách by mali byt' viac podporované rotáciou finančných nástrojov (bankové a obchodné úvery, RK a fondy podnikatel'ských anjelov, štátne dotácie, akademické zdroje, atd'.), a nie iba so zameraním na granty EÚ. Najviac patentované technológie v Pol'sku boli (v rokoch 1980-2014) organická jemná chémia (9 391 patentov), technológie v oblasti stavebného inžinierstva (9 260 patentov), a základná materiálová chémia (7 219 patentov). Tieto výsledky Pol'ska značne kopírujú hlavné zameranie technologických inovácií v rozvíjajúcich sa krajinách EÚ. Priemerne v tomto období rozvíjajúce sa krajiny vytvorili 29560 technologických patentov. Pričom nadpriemerné výsledky boli zaznamenané (v rámci tohto indikátora) v Bulharsku, Grécku, Mad'arsku, Pol'sku a Rumunsku. (Obrázok 2, Tab. 3 a 4)

Obrázok 2: Udelené technologické patenty podl’a krajín, WIPO (1980-2014)

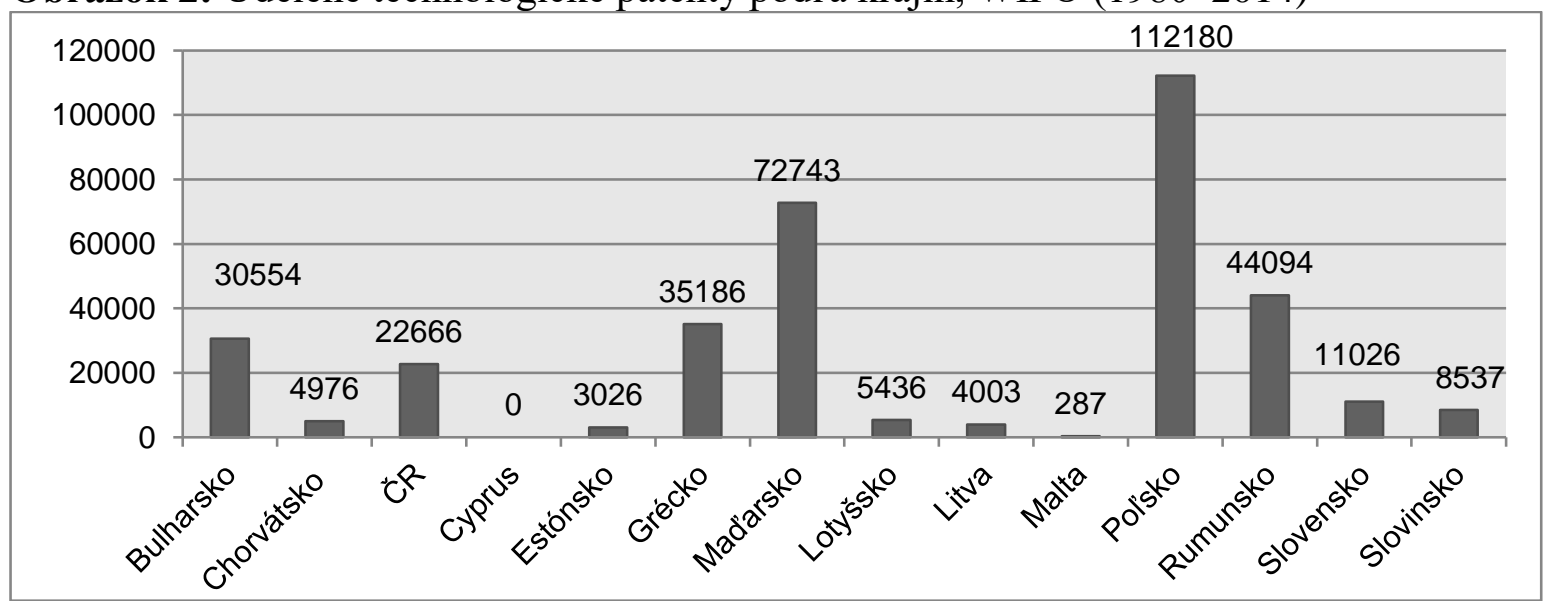

Zdroj: Vlastná štatistika na základe údajov (WIPO 2016)

\footnotetext{
${ }^{6}$ Pre: energetiku, životné prostredie, technológie, informačné a komunikačné technológie, zdravie a ekonomický rozvoj.

7 Patrí medzi ne napr. vedecko-technický park (Technopark Gliwice), technologické platformy (Inštitút neželezných kovov, Ústav hutníctva), Centrum pre informácie a transfer technológií pri Sliezskej technickej univerzite, inkubátory (New Gliwice) a akciové fondy (Accelerator Technology Gliwice).
} 
Tabul'ka 3: Udelené technologické patenty podl'a krajín a kategórií, WIPO (1980-2014), čast' A.

\begin{tabular}{|c|c|c|c|c|c|c|c|c|c|c|c|c|c|c|}
\hline Technologické kategórie & 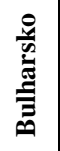 & 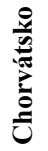 & 艺 & $\underbrace{\infty}_{0}$ & 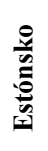 & 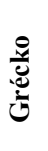 & 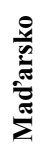 & 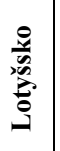 & 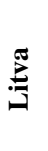 & 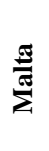 & $\begin{array}{l}\frac{0}{10} \\
\frac{0}{0} \\
\frac{0}{2}\end{array}$ & 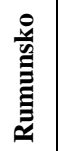 & $\begin{array}{l}\frac{\theta}{0} \\
\frac{\pi}{0} \\
\frac{\overrightarrow{0}}{\sigma}\end{array}$ & 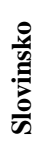 \\
\hline Elektrické zariadenia, prístroje, energia & $\stackrel{ \pm}{\Xi}$ & ڤิ & $\stackrel{\varrho}{\infty}$ & ○ & $\infty$ & is & $\begin{array}{l}\stackrel{a}{\circ} \\
\stackrel{2}{2}\end{array}$ & ミ & aे & $r$ & $\begin{array}{l}\stackrel{2}{2} \\
i \\
i n\end{array}$ & $\begin{array}{l}t \\
b \\
2 \\
N\end{array}$ & 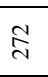 & $\begin{array}{l}\infty \\
n \\
n\end{array}$ \\
\hline Audiovizuálne technológie & 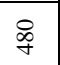 & チ & $\bar{d}$ & ○ & $\hat{m}$ & ڤ్ & สู & $\hat{n}$ & Y & - & $\stackrel{+}{ \pm}$ & $\stackrel{m}{\sim}$ & ळे & $\stackrel{8}{\circ}$ \\
\hline Dopravné zariadenia & $\tilde{\infty}$ & సิ & $\Xi$ & $\circ$ & ले & $\hat{\curvearrowright}$ & $\begin{array}{l}+\infty \\
\stackrel{D}{\Xi}\end{array}$ & 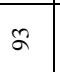 & $\approx$ & in & $\begin{array}{l}\mathbf{t} \\
\mathbf{b} \\
m\end{array}$ & $\underset{0}{0}$ & ஜ̊n. & g \\
\hline Medicínske technológie & $\stackrel{\Re}{n}$ & $\cong$ & 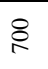 & $\circ$ & $\stackrel{M}{=}$ & ๙ু & సे & $\bar{\Xi}$ & $\stackrel{\infty}{\infty}$ & - & 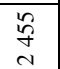 & $\stackrel{\circ}{\circ}$ & ठ̊ & $\overline{\grave{\lambda}}$ \\
\hline Organická jemná chémia & 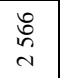 & $\stackrel{2}{\gtrless}$ & $\begin{array}{l}\stackrel{n}{o} \\
\text { cे } \\
\sim\end{array}$ & $\circ$ & $\stackrel{\infty}{\leftrightarrow}$ & ర్ర్రి & $\begin{array}{l}\stackrel{n}{o} \\
=\end{array}$ & 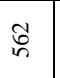 & 吕 & $\hat{\lambda}$ & बे & 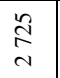 & $\stackrel{2}{2}$ & శ్రి \\
\hline Mechanické prvky & $\bar{n}$ & $\underline{\check{n}}$ & \& & $\circ$ & $\hat{m}$ & 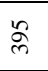 & $\begin{array}{l}\overrightarrow{8} \\
\sim\end{array}$ & i & 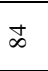 & $\sim$ & $\begin{array}{l}\hat{8} \\
+\end{array}$ & छे & : & ले \\
\hline Meracie zariadenia & 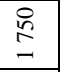 & t & $\stackrel{i}{i n}$ & ○ & $\stackrel{\circ}{n}$ & $\stackrel{m}{5}$ & $\begin{array}{l}\stackrel{8}{9} \\
\sim\end{array}$ & $\stackrel{ \pm}{m}$ & $\stackrel{\infty}{\infty}$ & $\circ$ & $\begin{array}{c}\hat{e} \\
-\end{array}$ & $\begin{array}{l}\stackrel{\infty}{n} \\
m\end{array}$ & $\stackrel{\infty}{\subseteq}$ & $\stackrel{\infty}{\sim}$ \\
\hline Manipulácia & ஜ̊ & $\stackrel{\infty}{n}$ & $\begin{array}{l}1 \\
\infty\end{array}$ & 0 & $\Xi$ & $\underset{\infty}{\infty}$ & 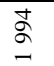 & $\stackrel{\infty}{=}$ & $\approx$ & $\bullet$ & \begin{tabular}{l}
$\overline{\widetilde{J}}$ \\
\multirow{\sigma}{*}{}
\end{tabular} & $\stackrel{\infty}{\exists}$ & fิ & $\tilde{n}$ \\
\hline Iné špeciálne zariadenia & $\underset{\sim}{\tilde{n}}$ & $\stackrel{\infty}{\approx}$ & 今ิ & $\circ$ & さ & $\underset{\sim}{\stackrel{2}{2}}$ & $\begin{array}{l}\text { ठิે } \\
\text { ल) }\end{array}$ & gे & $\Xi$ & $n$ & $\frac{\vec{m}}{n}$ & $\underset{\infty}{\infty}$ & $\stackrel{\sim}{f}$ & $\stackrel{\infty}{\check{m}}$ \\
\hline Textilné a papierenské stroje & $\stackrel{+}{8}$ & ケ & $\aleph_{\infty}$ & $\circ$ & $\stackrel{e}{2}$ & 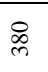 & సે & a & $\stackrel{\infty}{\curvearrowright}$ & + & $\begin{array}{l}\text { 文 } \\
\underset{\sim}{\sim}\end{array}$ & 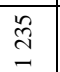 & $\ddot{\varkappa}$ & 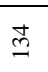 \\
\hline Počítačové technológie & 呑 & $\stackrel{i}{i}$ & $\cong$ & $\circ$ & q & 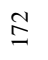 & ठి & $\bar{m}$ & $\infty$ & $\mathrm{N}$ & $\vec{\infty}$ & $\stackrel{\infty}{\sim}$ & $\sqrt{2}$ & $\bar{\sigma}$ \\
\hline Farmaceutické technológie & $\begin{array}{l}\because \\
\infty \\
\infty\end{array}$ & శ్ర & 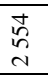 & ○ & $\bar{b}$ & $\begin{array}{l}\frac{0}{+} \\
\text { N } \\
\end{array}$ & $\underset{5}{\frac{5}{5}}$ & હે & बे & $\stackrel{i}{i}$ & \begin{tabular}{l}
$\stackrel{2}{2}$ \\
\multirow{+}{*}{}
\end{tabular} & $\begin{array}{l}\text { Oे } \\
\text { d } \\
\text { d }\end{array}$ & $\stackrel{0}{2}$ & $\mathscr{\infty}$ \\
\hline Základná materiálová chémia & है & 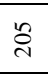 & 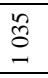 & ○ & 年 & $\begin{array}{l}\underset{\infty}{+} \\
- \\
\end{array}$ & $\begin{array}{l}y \\
\text { fy } \\
\rightarrow\end{array}$ & ڤે & $\cong$ & $r$ & $\stackrel{\vec{N}}{\sim}$ & $\begin{array}{l}\text { Oे } \\
\text { nे } \\
\sim\end{array}$ & 守 & $\widetilde{\approx}$ \\
\hline Optické zariadenia & సี & 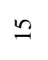 & 肙 & $\circ$ & $\infty$ & 尔 & $\frac{n}{n}$ & i & in & - & 㚙 & $\stackrel{n}{d}$ & $\approx$ & $\infty$ \\
\hline Motory, čerpadlá, turbíny & 点 & ले & $\tilde{n}$ & ○ & $\stackrel{i}{i}$ & $\stackrel{?}{\stackrel{9}{子}}$ & $\begin{array}{l}\stackrel{0}{2} \\
=\end{array}$ & 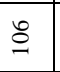 & $\stackrel{\infty}{\varrho}$ & N & $\begin{array}{l}\vec{\sim} \\
\stackrel{\sim}{N}\end{array}$ & $\stackrel{5}{\Xi}$ & $\frac{n}{N}$ & $\stackrel{\infty}{=}$ \\
\hline Makromolekulárna chémia, polyméry & సे & 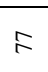 & 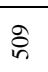 & $\circ$ & $\approx$ & $\stackrel{\infty}{\infty}$ & $\begin{array}{l}\text { 兌 } \\
\text { in }\end{array}$ & in & 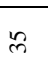 & 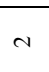 & $\stackrel{\underline{I}}{\mathrm{~m}}$ & $\hat{\mathrm{o}}$ & 今े & $\Xi$ \\
\hline Obrábacie stroje & $\stackrel{\text { : }}{-}$ & $\cong$ & $\frac{\pi}{\sigma}$ & $\circ$ & $\bar{n}$ & 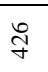 & రิ & $\Xi$ & $\curvearrowleft$ & + & $\underset{\Xi}{\stackrel{\vartheta}{\sigma}}$ & $\underset{n}{n}$ & ฟิ & $\stackrel{\sim}{\sim}$ \\
\hline Stavebné inžinierstvo & g & ஓे & ले & o & 导 & $\begin{array}{l}\text { ¿े } \\
\text { - }\end{array}$ & 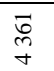 & 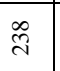 & :्ञे & $\sqrt{2}$ & $\begin{array}{l}\stackrel{8}{0} \\
\text { a }\end{array}$ & $\frac{\tilde{\sigma}}{\sim}$ & : & $i$ \\
\hline Telekomunikácie & ิㅗㅇ & 尺े & $\supseteqq$ & ○ & 过 & సิ & $\bar{\Omega}$ & 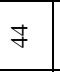 & $\infty$ & + & $\stackrel{2}{2}$ & $\stackrel{\sim}{\check{\lambda}}$ & f & $\infty$ \\
\hline Digitálna komunikácia & 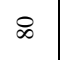 & ส & $\bar{\Xi}$ & o & $\infty$ & $\approx$ & తి & 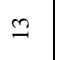 & & o & ते & in & $\stackrel{4}{a}$ & q \\
\hline Chemické inžinierstvo & $\underset{\mathrm{N}}{\stackrel{\text { I }}{ }}$ & $\bar{I}$ & రి & ○ & $\approx$ & ถิ & $\begin{array}{l}\vec{\rho} \\
\stackrel{\alpha}{N} \\
\sim\end{array}$ & 守 & I & 6 & $\begin{array}{l}\bar{i} \\
\text { in }\end{array}$ & مू & $\stackrel{q}{q}$ & లె \\
\hline Materiály, hutníctvo & $\begin{array}{l}n \\
\infty \\
\infty \\
-\end{array}$ & $\stackrel{\varrho}{\varrho}$ & \& & 0 & $\ddot{m}$ & $\stackrel{8}{n}$ & $\begin{array}{l}\vec{J} \\
\overrightarrow{0} \\
\mathrm{~N}\end{array}$ & $\approx$ & $\widetilde{\varrho}$ & $\mathrm{N}$ & $\begin{array}{l}t \\
\text { d. } \\
\text { in }\end{array}$ & $\begin{array}{l}\hat{\sigma} \\
\text { ते }\end{array}$ & $\stackrel{\Re}{f}$ & in \\
\hline Biotechnológie & $\stackrel{2}{2}$ & $\stackrel{\infty}{=}$ & $\stackrel{2}{g}$ & o & $\stackrel{ \pm}{I}$ & $\stackrel{尺}{\circ}$ & $\begin{array}{l}\text { 咅 } \\
\text { N }\end{array}$ & $\stackrel{œ}{\cong}$ & $\mathscr{\infty}$ & 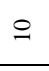 & $\stackrel{\bar{\infty}}{\stackrel{-}{\beth}}$ & 导 & $\stackrel{\infty}{+}$ & $\stackrel{n}{\simeq}$ \\
\hline Polovodiče & 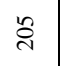 & 6 & in & ○ & $\circ$ & $\stackrel{\infty}{i}$ & $\widetilde{\sigma}$ & $\simeq$ & ते & - & $\underset{f}{\stackrel{f}{f}}$ & 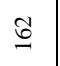 & $\stackrel{\circ}{\square}$ & ల \\
\hline Ostatný spotrebný tovar & లెల & $\stackrel{0}{1}$ & $\vec{n}$ & $\circ$ & m & $\frac{n}{6}$ & $\hat{\sigma}$ & $\infty$ & $\bar{\Xi}$ & $a$ & 음 & 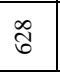 & $\stackrel{n}{2}$ & $\stackrel{n}{m}$ \\
\hline Nábytok, hry & $\stackrel{\infty}{\infty}$ & $\underline{6}$ & 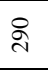 & $\circ$ & $\bar{m}$ & 今े & $\stackrel{q}{\stackrel{m}{m}}$ & $\stackrel{n}{=}$ & 2 & 6 & 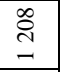 & $\underset{i n}{t}$ & $\stackrel{\circ}{\varrho}$ & ते \\
\hline Povrchové technológie, nátery & \& & $\stackrel{\infty}{+}$ & $\stackrel{\substack{\infty \\
\infty}}{n}$ & $\circ$ & $\hat{\sim}$ & 总 & $\stackrel{\infty}{\curvearrowleft}$ & 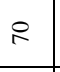 & $\stackrel{8}{\circ}$ & $\sim$ & $\begin{array}{l}n \\
\infty \\
\sim \\
\sim\end{array}$ & สิ & $\stackrel{8}{\circ}$ & $\stackrel{M}{=}$ \\
\hline Kontrolné technológie & $\stackrel{8}{\rightarrow}$ & $\cong$ & సి & $\circ$ & ల & $\stackrel{\sim}{\sim}$ & $\stackrel{\infty}{\infty}$ & $\mathscr{F}$ & $\infty$ & $\circ$ & f & $\underset{\widetilde{b}}{\infty}$ & 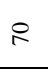 & $\stackrel{M}{2}$ \\
\hline Tepelné procesy a zariadenia & $\stackrel{\infty}{\stackrel{\sigma}{\sigma}}$ & 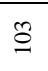 & $\stackrel{\infty}{i \infty}$ & $\circ$ & F & $\mathbb{0}_{0}^{\infty}$ & 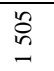 & $\kappa$ & $\stackrel{\beth}{1}$ & 0 & $\begin{array}{l}\vec{v} \\
\stackrel{\omega}{N} \\
v\end{array}$ & $\Re$ & $\stackrel{\varrho}{=}$ & $\vec{n}$ \\
\hline
\end{tabular}

Zdroj: Vlastná štatistika na základe údajov (WIPO 2016) 
Tabul'ka 4: Udelené technologické patenty podl'a krajín a kategórií, WIPO (1980-2014), čast' B.

\begin{tabular}{|c|c|c|c|c|c|c|c|c|c|c|c|c|c|c|}
\hline Technologické kategórie & 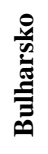 & 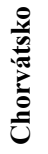 & 气ี & $\stackrel{n}{0}$ & 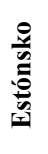 & 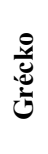 & 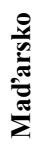 & 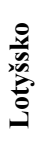 & 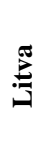 & $\frac{\text { ज्ञ }}{\sum^{\pi}}$ & $\begin{array}{l}\frac{0}{0} \\
\frac{0}{0} \\
\frac{0}{2}\end{array}$ & 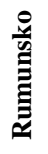 & $\begin{array}{l}\frac{8}{0} \\
\frac{\pi}{0} \\
\frac{0}{0}\end{array}$ & $\frac{8}{\frac{8}{0}}$ \\
\hline Základné komunikačné procesy & ळે & $=$ & 于 & 0 & $\stackrel{4}{2}$ & 8 & $\stackrel{n}{q}$ & $\stackrel{0}{2}$ & $=$ & N & $\overbrace{\substack{0\\
}}^{9}$ & $\ddot{\sim}$ & F & $\stackrel{i}{m}$ \\
\hline Environmentálne technológie & సे & $\Xi$ & $\stackrel{n}{n}$ & 0 & r & $\underset{\infty}{\infty}$ & 惫 & $\infty$ & $\stackrel{\mathscr{I}}{\simeq}$ & $m$ & $\stackrel{2}{2}$ & 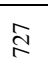 & $\bar{\approx}$ & $\Xi$ \\
\hline Potravinárska chémia & $\stackrel{\wp}{\varrho}$ & $\cong$ & 字 & 0 & 8 & $\bar{\sigma}$ & $\overrightarrow{\widehat{\delta}}$ & \&্ল & $\stackrel{\sim}{\sim}$ & - & $\begin{array}{l}2 \\
\infty \\
\infty \\
-1\end{array}$ & ڤे & 点 & $\stackrel{m}{m}$ \\
\hline Analýza biologických materiálov & $\overline{\tilde{\lambda}}$ & $\stackrel{\infty}{-}$ & $\stackrel{\infty}{\stackrel{\infty}{\leftrightarrows}}$ & $\circ$ & $\ddot{n}$ & $\stackrel{8}{n}$ & 字 & F & $\hat{\imath}$ & 0 & ه̊ & ปิ & in & 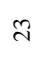 \\
\hline IT pre manažment & r & $\cong$ & त) & 0 & $=$ & q & $m$ & $r$ & $\simeq$ & 0 & $\bar{\lambda}$ & $\infty$ & r & $m$ \\
\hline $\begin{array}{l}\text { Mikroštrukturálne technológie a } \\
\text { nanotechnológie }\end{array}$ & N & 0 & ले & 0 & $m$ & 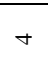 & 0 & in & - & 0 & 只 & $r$ & $m$ & 2 \\
\hline Iné & $\stackrel{\mathscr{O}}{\infty}$ & $\ddot{\imath}$ & - & 0 & - & $\begin{array}{l}\Omega \\
\beth\end{array}$ & $\stackrel{5}{5}$ & 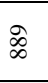 & 0 & $\stackrel{\Xi}{\Xi}$ & $\stackrel{\infty}{\infty}$ & $\underset{\sim}{\infty}$ & - & 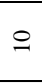 \\
\hline Suma & 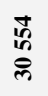 & ڤ̊ & $\begin{array}{l}\text { : } \\
\text { స̃ }\end{array}$ & 0 & ֻัّ & $\stackrel{\infty}{\stackrel{\infty}{\infty}}$ & $\underset{\frac{\pi}{N}}{\stackrel{T}{N}}$ & 苛 & 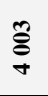 & ্ָণ & $\begin{array}{l}\underset{\mathscr{\Xi}}{\simeq} \\
\Xi\end{array}$ & $\begin{array}{l}\text { I } \\
\text { J }\end{array}$ & $\begin{array}{l}\text { İ } \\
\Xi \\
\Xi\end{array}$ & 芯 \\
\hline$\%$ & हे & $\bar{\delta}$ & $\stackrel{\circ}{8}$ & है: & $\bar{\theta}_{0}$ & $\stackrel{8}{\circ}$ & సู & 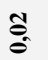 & है & $\stackrel{8}{8}$ & $\widetilde{\sigma}^{\tilde{2}}$ & $\frac{7}{8}$ & $\stackrel{0}{8}$ & $\stackrel{\tilde{\delta}}{0}$ \\
\hline
\end{tabular}

Zdroj: Vlastná štatistika na základe údajov (WIPO 2016)

\section{Záver}

Táto výskumná štúdia bola zameraná na vybrané pozitívne a negatívne aspekty podpory, ekonomiky a patentovania technologických inovácií v rozvíjajúcich sa krajinách EÚ, aby boli v rámci možností identifikované hlavne tie problematické oblasti, ktoré by tieto členské štáty EÚ mali najprv odstraňovat', pre viac cielené, efektívne a udržatel'né technologické inovácie, ktoré môžu byt' jedným z determinantov ich socioekonomického rozvoja. Nie každá technologická inovácia môže byt' patentovaná, ale každý patent musí byt' transformovaný do nových výrobkov, technológií alebo dizajnov, než bude komerčne úspešný. Podl'a nášho výskumu najmä patentovej databázy WIPO (1980-2014), možno uviest', že podl'a uvedených ukazovatel’ov v tejto štúdií, technologická inovačná intenzita je značne rozdielna aj medzi rozvíjajúcimi sa krajinami EÚ. Medzi technologicky najúspešnejšie rozvíjajúce sa krajiny EÚ patria najmä Pol'sko, Mad'arsko a Rumunsko (podl'a tejto časti štúdie). Viac úspešnejšie krajiny sú aj Grécko a Bulharsko. A najmenej úspešné sú najmenšie ekonomiky Malta a Cyprus. Napr. Cyprus neregistroval žiadne technologické patenty v databáze WIPO v období 1980-2014. Najviac patentované technológie v rozvíjajúcich sa krajinách EÚ sú v kategóriách: organická jemná chémia (10,2\%), nasledujú farmaceutické technológie $(7,6 \%)$ a stavebné inžinierstvo $(6,2 \%)$, pre ktoré majú tieto krajiny často viac historicky vytvorené predpoklady a skúsenosti. Naopak najmenej patentované technológie v rozvíjajúcich sa krajinách EÚ sú mikroštrukturálne technológie a nanotechnológie $(0,03 \%)$, IT pre manažment $(0,06 \%)$ a digitálna komunikácia $(0,3 \%)$. Celkovo rozvíjajúce sa krajiny sa podiel'ajú na patentovaní technológií v EÚ približne len 14\%.

$\mathrm{Na}$ základe tejto štúdie medzi klúčové príčiny technologickej inovačnej rozdielnosti i celkového inovačného zaostávania rozvíjajúcich sa krajín EÚ možno zaradit' aj tieto problémy. Po prvé to môže byt' dlhodobá izolácia od globálneho technologického vývoja, vzhl'adom k celkovej ekonomickej izolácii mnohých postkomunistických krajín EÚ. Na rozdiel od mnohých vyspelých krajinách EÚ, investície do VaV nových technológií môžu byt' považované za "sekundárne" (zvyčajne zahraničné, alebo vládne) investície (Schumpeter 
2005). V týchto krajinách nie je často príliš priaznivá sociálno-ekonomická situácia, motivácia i presvedčenie o primárnej účelnosti investícií do technológií, pretože najprv je potrebné podporovat' viac operatívne projekty (predovšetkým zamerané na infraštruktúru, zdravotníctvo, alebo sociálne otázky). Vel’a krát chýba primeraná strategická vízia a dlhodobé ciele technologického rozvoja. Mnohé vyspelé ekonomiky systematicky využívajú procesy foresightu pre dlhodobé plánovanie a podporu kl'účových národných technológií, čo môže byt' pozitívnym príkladom aj pre rozvíjajúce sa krajiny EÚ. Ďalším problémom je stále málo otvorený, menej atraktívny, menej excelentne zameraný a slabo podporovaný národný systém VaV i ochrany DV. Naopak systém ochrany DV je často vel'mi nákladný a prehnane časovo i administratívne náročný najmä pre MSP i univerzity. V malých ekonomikách nie je však často opodstatnenie budovat' komplikovaný národný systém ochrany DV, pre celkovú menšiu konkurenciu na trhu. Je tiež známe, že mnohé európske výskumné tímy často duplikujú VaV $\mathrm{v}$ technologických oblastiach, čo prináša rôzne neefektívnosti aj pre programy EK. Všetky tieto obmedzujúce faktory a ich vývoj potvrdzujú naše predpoklady, aj ked' nie je možné reálne vyčíslit' ich vplyv na socioekonomický vývoj krajiny. Naopak strategicky zamerané, systematické, účelné, presné a efektívne financovanie a manažment vedy a výskumu môže priniest' do ekonomiky viac zdrojov, nové kapacity a zvyšovanie celkového životného štandardu l'udí. Tieto problémy však možno identifikovat' u väčšiny analyzovaných krajín, takže ich odstraňovanie môže byt' dobrým predpokladom pre zvyšovanie technologickej konkurencie i socioekonomického štandardu v týchto krajinách.

\section{Literatúra}

[1] CHRISTENSEN, C. M. and M. E. RAYNOR, 2003. The Innovator's Solution: Creating and Sustaining Successful Growth. Cambridge, Massachusetts: Harvard Business School Press. ISBN 1578518520.

[2] CIPA, 2016. Research and Development. The Cyprus Investment Promotion Agency [online]. [vid. 5. marca 2016]. Dostupné z: http://www.cipa.org.cy/en/growthsectors/cyprus-investment-sectors/research-and-technology-sector

[3] CORDIS, 2008. European activities in the field of ethical, legal and social aspects (ELSA) and governance of nanotechnology. Cordis [online]. [vid. 15. marca 2016]. Dostupné http://cordis.europa.eu/pub/nanotechnology/docs/elsa_governance_nano.pdf

[4] DOLATA, U., 2008. The Transformative Capacity of New Technologies. How Innovations Affect Sectoral Change: Conceptual Considerations. Cologne: Max Planck Institute for the Study of Societies. Discussion Paper, 8(2), 1-28. ISSN 0944-2073.

[5] DOLATA, U., 2009. Technological innovation and sectoral change. Transformative capacity, adaptability, patterns of change: An analytical framework. Research policy, 38(6), 1066-1076. ISSN 0048-7333.

[6] EC, 2009. Risk Assessment of Products of Nanotechnologies. EC [online]. [vid. 5. marca 2016].

Dostupné

Z: http://ec.europa.eu/health/ph_risk/committees/04_scenihr/docs/scenihr_o_023.pdf

[7] EC, 2013. Enterprise and Industry Innovation Union Scoreboard. EC [online]. [vid. 11. marca 2016]. Dostupné z: http://ec.europa.eu/enterprise/policies/innovation/files/ius2013_en.pdf

[8] EC, 2014. The EU explained: Digital agenda for Europe. EC [online]. [vid. 12. marca 2016]. Dostupné z: http://europa.eu/pol/pdf/flipbook/en/digital_agenda_en.pdf 
[9] EC, 2015a. The Innovation Union Scoreboard report 2015. EC [online]. [vid. 11. februára 2016]. Dostupné z: http://ec.europa.eu/growth/industry/innovation/factsfigures/scoreboards/files/ius-2015_en.pdf

[10] EC, 2015b. Industry and construction statistics - short-term indicators. EC [online]. [vid. 10. februára 2016]. Dostupné z: http://ec.europa.eu/eurostat/statisticsexplained/index.php/Industry_and_construction_statistics_-_short-term_indicators

[11] ECB, 2016. Rozvíjajúce sa ekonomiky. ECB [online]. [vid. 14. marca 2016]. Dostupné z: https://www.ecb.europa.eu/ecb/tasks/international/emerging/html/index.sk.html

[12] EDGINGTON, D. W., 2008. The Japanese Innovation System: University-Industry Linkages, Small Firms and Regional Technology Clusters. Prometheus, 26(1), 1-18. ISSN 0810-9028.

[13] EFPIA, 2014. The Pharmaceutical Industry in Figures. The European Federation of Pharmaceutical Industries and Associations [online]. [vid. 18. februára 2016]. Dostupné Z: http://www.efpia.eu/uploads/Figures_2014_Final.pdf

[14] EUROPARL.EUROPA, 2016. 40 rokov rozširovania EÚ. Európsky parlament [online]. [vid. $11 . \quad$ apríla 2016]. Dostupné z: http://www.europarl.europa.eu/external/html/euenlargement/default_sk.htm

[15] IPTS, 2016. Manufacture of Organic Fine Chemicals. EC [online]. [vid. 19. mája 2016]. Dostupné z: http://eippcb.jrc.ec.europa.eu/reference/ofc.html

[16] JEMALA, M., 2012. Nature of Foresight Planning. Saarbrücken: LAP LAMBERT Academic Publishing. ISBN 978-3659131509.

[17] JEMALA, M., 2014. Technology identification: How to bring technology innovation to life? Saarbrücken: Scholars' Press. ISBN 978-3-639-71044-1.

[18] JEMALA, M., 2015. Systemic insights into nanotechnology patenting in EU countries. Journal of Agile Systems and Management, 8(1), 1-22. ISSN 1741-9174.

[19] JEMALA, M. and L'. JEMALA, 2014. Key Sub-Disciplines and Methods of Technology Planning in Dynamic Environment. Acta Oeconomica Pragensia, 22(2), 71-84. ISSN 0572-3043.

[20] NOWAK, A., 2009. High Tech and Societal Innovation in Poland: Prospects and Strategies. Journal of Economics and Business, 7(1), 10-17. ISSN 1108-2992.

[21] OECD, 2013. OECD Science, Technology and Industry Scoreboard 2013, Innovation for Growth. OECD [online]. [vid. 11. novembra 2016]. Dostupné z: http://www.oecdilibrary.org/docserver/download/9213051e.pdf?expires=1393853624\&id=id\&accname =guest\&checksum=1612E500D2382D6B68D378BF28AFCC70

[22] RUSSELL, R. S. and B. W. TAYLOR, 2014. Operations and Supply Chain Management. Chichester: John Wiley and Sons Ltd. ISBN 978-1118808900.

[23] SCHUMPETER, J. A., 2005. Business cycles: A theoretical, historical, and statistical analysis of the capitalist process. NY: McGraw-Hill. ISBN 1578985560.

[24] TIDD, J. and J. BESSANT, 2015. Innovation and Entrepreneurship. Chichester: John Wiley and Sons Ltd. ISBN 978-1118993095.

[25] TRAMOUNTANELli, P., 2010. Patents in Cyprus. KYPRIANOU [online]. [vid. 16. decembra 2016].

Dostupné

$\mathrm{Z}$ : 
http://www.kyprianou.com.cy/assets/mainmenu/31/editor/Patents\%20in\%20Cyprus\%2 0_\%20by\%20Phivi\%20Tramountanelli.pdf

[26] TVEDT, M. W., 2010. One Worldwide Patent System: What's in it for developing countries? Third World Quarterly, 31(2), 227-293. ISSN 0143-6597.

[27] UNDP, 2015. Human Development Report 2015. UN [online]. [vid. 8. septembra 2016]. Dostupné http://hdr.undp.org/sites/default/files/2015_human_development_report.pdf

[28] USPTO, 2014. Patents by Country, State, and Year - All Patent Types. USPTO [online]. [vid. $7 . \quad$ marca 2016]. Dostupné http://www.uspto.gov/web/offices/ac/ido/oeip/taf/cst_all.htm

[29] WIPO, 2015. World Intellectual Property Report. WIPO [online]. [vid. 7. júna 2016]. Dostupné z: http://www.wipo.int/edocs/pubdocs/en/wipo_pub_944_2015.pdf

[30] WIPO, 2016. Patents grants by technology, Total account by filling office, EPO. WIPO [online]. [vid. 11. februára 2016]. Dostupné z: http://ipstatsdb.wipo.org/ipstatv2/

[31] YANG, D. Y., 2005. Technological innovation and future research needs in net shape manufacturing. Numisheet, A(CP778), 8-11. ISBN 0-7354-0265-5. 